\title{
Thermo-physiological properties of woven structures in wet state
}

\section{REZUMAT - ABSTRACT}

Proprietățile termofiziologice ale structurilor țesute în stare umedă

\begin{abstract}
Parametrii cei mai performanți care măsoară confortul termofiziologic al articolelor de îmbrăcăminte sunt conductivitatea termică, absorbția termică și permeabilitatea la vaporii de apă. În această lucrare, confortul termofiziologic a fost studiat pentru diferite structuri de țesături și grade de umiditate. Proprietățile termice și permeabilitatea la vapori de apă în stare uscată și umedă a tuturor probelor de țesătură au fost determinate de către ALAMBETA și, respectiv, Permetest. Rezultatele au arătat că structura țesăturii și compoziția firelor în bătătură influențează puternic proprietățile termice și permeabilitatea la vaporii de apă în prezența umidității. Probele de țesătură au fost proiectate prin modificarea tipului de legătură și a compoziției fibroase a bătăturii. În stare umedă, cu un conținut de umiditate de până la $20 \%$, structurile de țesătură au prezentat un comportament nesemnificativ pentru proprietățile termice datorită fracției de oxigen. Pe măsură ce conținutul de umiditate crește, țesătura cu fire de bătătură din poliester a oferit o senzație mai mare de rece la contactul cu pielea.
\end{abstract}

Cuvinte-cheie: model de legătură, conductivitate termică, absorbție termică, permeabilitate la vapori de apă, conținut de umiditate (stare umedă)

\section{Thermo-physiological properties of woven structures in wet state}

The utmost parameters that measure the thermo-physiological comfort of garments are thermal conductivity, thermal absorptivity and water vapor permeability. In this paper, thermo-physiological comfort was studied with different weave design and moisture content. Thermal properties and water vapor permeability in dry and wet state of all fabric samples were determined by ALAMBETA and Permetest respectively. Results showed that the weaving structure and yarn composition in weft were closely related to the thermal properties and water vapor permeability in presence of moisture. Woven fabric samples were constructed by varying the weave design and weft composition. In wet state, moisture content up to $20 \%$, weave structures exhibited non-significant behavior for thermal properties due to air fraction. As the moisture content enhanced, woven structure made with polyester weft yarn provided cooler feeling with skin contact.

Keywords: weaving design, thermal conductivity, thermal absorptivity, water vapor permeability, moisture content (wet state)

\section{INTRODUCTION}

Thermo-physiological comfort of clothing is an important issue for everyday body wear, protective garments, sportswear and varying end of use application. It concerns the psychological, physiological and physical harmony between human body and the external environment conditions [1]. Nowadays, consumers require clothes which provide comfort and protection of the body against environmental conditions while performing different physical activities [2]. During high activities and/or high atmospheric temperature, sweat glands get activated and produce perspiration in its liquid and vapour form. Clothes should allow the passage of perspiration through it, otherwise it leads to discomfort. Discomfort principally results from the build-up of sweat on the skin [3]. The main role of clothing is the protection of human body against the harmful effects of external environment and to promote the own thermoregulatory function in different environmental conditions, while performing various physical activities. The fabric as a protection layer creates and regulates the appropriate microclimate around the skin, which is strongly influenced by the wearer physiological comfort [4]. Contrary to a commonly accepted theory garments, due to sweat sorption or because of humid, rainy climate are often used in wet state, which has influence on their comfort properties. The thermo-physiological comfort of wet fabrics is given by the active cooling resulting produce from the moisture evaporation of the skin and passing through the garment and from direct evaporation of sweat from the fabric surface [5-6].

Many studies on water vapor permeability of textile fabrics have been conducted [7-9], but there is a warm/cool feeling still no taken into consideration due to the moisture content. This follows from the fact that current measuring instruments for the evaluation of the properties usually require more than 30 minutes for full reading, avoiding the precise determination of humidity effect on their cooling heat flow $\left[\mathrm{W} / \mathrm{m}^{2}\right]$, which decrease during the measurement.

Thermal properties of textiles such as thermal conductivity and thermal absorptivity are important parameters that influence thermal comfort of fabrics and continue to be the subject of many studies 
[10-12]. The knowledge of thermal properties of fabrics in dry state is important but the most important is to know the effect in wet state to simulate the real feeling of the wearer especially when a fabric is designed for people working under moist conditions [10]. With the increasing in moisture regain thermal properties of fabrics changes and affects adversely thermo-physiological comfort of wearer. Theories characterizing thermal properties of fabrics in wet state are not sufficient in the literature. To understand the mechanism, it was further studied the effect of moisture regain on thermal conductivity of woven fabrics [11]. The thermal conductivity grows up with the increase of percentage of moisture in the fabric [12]. Thermal conductivity indicates the ability of a material to allow the passage of heat through due to change in temperature. Thermal conductivity is anisotropic in nature and largely depends upon the structure of the material. A fabric is composed of polymers (fibers), air trapped inside the fabric, and moisture present in voids [13-14]. In clothing comfort, there is a thermal property relates warm/cool feeling, called thermal absorptivity $(b)\left[\mathrm{Ws}^{1 / 2} /\left(\mathrm{m}^{2} \cdot \mathrm{K}\right)\right]$ which was firstly introduced by Lubos Hes. This parameter allows the assessment of fabric's character in the aspect of its "warm /cool" feeling [15].

WVP (water vapor permeability) in dry state is easy to understand and measure but in wet condition it is difficult to measure. A water film is produced on the surfaces which lessen the flow of permeability in fabric $[9,16]$. Simultaneously, wet skin can greatly increase the cooling effect can be created by wet body skin results in formation of drop compared to the dry fabric. Water vapor permeability measurements by WVP testers has a drawback of long time period therefore Skin Model Type (Permetest Sensora Skin Model) is suitable for WVP evaluation of fabric along within wet state [17].

\section{MATERIAL AND METHODS}

\section{Material}

Woven fabric used for the study consists of three basic weave structures (plain, twill and satin) as shown in figure 1.

The detail of fabrication is listed in table 1. Warp density is 24 ends/cm and weft density is 21 picks per $\mathrm{cm}$.

Table 1

\begin{tabular}{|c|c|c|c|c|c|}
\hline $\begin{array}{l}\text { Sample } \\
\text { number }\end{array}$ & $\begin{array}{c}\text { Weave } \\
\text { struc- } \\
\text { ture }\end{array}$ & Warp & Weft & $\begin{array}{l}\text { Weight } \\
\left(\mathrm{g} / \mathrm{m}^{2}\right)\end{array}$ & $\begin{array}{c}\text { Thickness } \\
\text { (mm) }\end{array}$ \\
\hline 1 & Plain & \multirow{6}{*}{$\begin{array}{c}\text { PC } \\
(50: 50) \\
30 \text { tex }\end{array}$} & \multirow{3}{*}{$\begin{array}{c}\text { PC } \\
(50: 50) \\
30 \text { tex }\end{array}$} & 165 & 0.43 \\
\hline 2 & Twill 3/1 & & & 166 & 0.52 \\
\hline 3 & Satin $4 / 1$ & & & 167 & 0.51 \\
\hline 4 & Plain & & \multirow{3}{*}{$\begin{array}{c}20 \text { tex } \\
100 \% \\
\text { Polyester }\end{array}$} & 131 & 0.34 \\
\hline 5 & Twill 3/1 & & & 134 & 0.44 \\
\hline 6 & Satin 4/1 & & & 135 & 0.43 \\
\hline
\end{tabular}

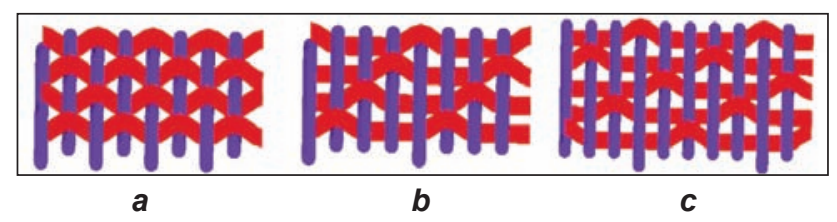

Fig. 1. Weave structure of three basic designs: $a$ - plain; $b$ - twill; $c$ - satin

Rapier weaving machine (GamMax Picanol) was used to make all woven sample.

\section{Methods}

After pretreatments, all samples were tested for thermal properties and water vapor permeability in standard environmental conditions at $20-22^{\circ} \mathrm{C}$ temperature and $50-55 \%$ relative humidity.

\section{Thermal conductivity}

Thermal conductivity coefficient " $\lambda$ " presents the amount of heat, which passes from one square meter area of material through the distance one meter within one second and create the temperature difference of one Kelvin. Thermal conductivity of textile structures generally reaches levels from 0.033 to 0.01 $\mathrm{W} / \mathrm{m} / \mathrm{K}$. Thermal conductivity of steady air by $20^{\circ} \mathrm{C}$ is $0.026 \mathrm{~W} / \mathrm{m} / \mathrm{K}$, while thermal conductivity of water is $0.6 \mathrm{~W} / \mathrm{m} / \mathrm{K}$, which is 25 times more. Therefore, the water presence in textile materials is undesirable [12].

\section{Thermal absorptivity}

Thermal absorptivity (b) of fabrics was firstly proposed by Lubos Hes to characterize thermal feeling (heat flow level) during short contact of human skin with the fabric surface [15]. Providing that the time of heat contact $(\tau)$ between the human skin and the textile is shorter then several seconds, the measured fabric can be simplified into semi-infinite homogenous mass with certain thermal capacity $\rho c\left[\mathrm{~J} / \mathrm{m}^{3}\right]$ and initial temperature $t_{2}$. Unsteady temperature field between the human skin (with constant temperature $t_{1}$ ) and fabric with respect to boundary conditions offers a relationship, which enables to determine the heat flow $q\left[\mathrm{~W} / \mathrm{m}^{2}\right]$ course passing through the fabric:

$$
q=\frac{b\left(t_{1}-t_{2}\right)}{(\pi \tau)^{1 / 2}}, \quad b=(\lambda \rho c)^{1 / 2}
$$

Where $\rho c\left[\mathrm{~J} / \mathrm{m}^{3}\right]$ is thermal capacity of the fabric and the term $b$ presents thermal absorptivity of fabrics. The higher is thermal absorptivity of the fabric, the cooler is its feeling.

\section{Relative water vapor permeability}

Relative water vapor permeability was measured on a Permetest instrument by a similar procedure to that given by Standard ISO 11092 [18]

Principle of ALAMBETA instrument - A tester for thermal properties of fabrics

ALAMBETA instrument was used to measure thermal conductivity and thermal absorptivity of fabrics. The 
Alambeta simulates the dry human skin and its principle depends in mathematical processing of time course of heat flow passing through the tested fabric due to different temperatures of bottom measuring plate $\left(22^{\circ} \mathrm{C}\right)$ and measuring head $\left(32^{\circ} \mathrm{C}\right)$. When the specimen is inserted, the measuring head drops down, touches the fabrics and the heat flow levels are processed in the computer and thermo-physical properties of the measured specimen are evaluated [15]. The contact pressure fixed at $200 \mathrm{~Pa}$, and the CV values for all the samples were lower than $5 \%$.

\section{PERMETEST}

In wet state, the samples were first dried in an oven at $110^{\circ} \mathrm{C}$, in order to remove the moisture and weighted immediately to record the dry weight of the fabrics. To increase the humidity, the samples were immersed in their full volume with water containing a surfactant to lower the surface tension. After taking out, fabrics specimen were weighed again to check the amount of moisture gained. Samples were experimented by Alambeta and then placed horizontally on a net made of nylon string stand. This procedure was carried out to allow free evaporation of water molecule from the fabric.

\section{Moisture regain calculation}

The moisture content or the mass increase $M_{n}(\%)$ due to absorbed moisture was calculated as follow [6]

Where:

$$
M_{n}(\%)=\frac{W_{W e t}-W_{d r y}}{W_{d r y}} \cdot 100
$$

$M_{n}(\%)$ is fabric relative moisture content;

$W_{\text {Wet }}$ - fabric weight in wet state;

$W_{d r y}$ - fabric weight in dry state.

\section{RESULTS AND DISCUSSION}

\section{Thermal conductivity}

Thermal conductivity $(\lambda)$ is an intensive and specific property of materials. Thermal conductivity of water is approximately 25 times higher than that of dry textile

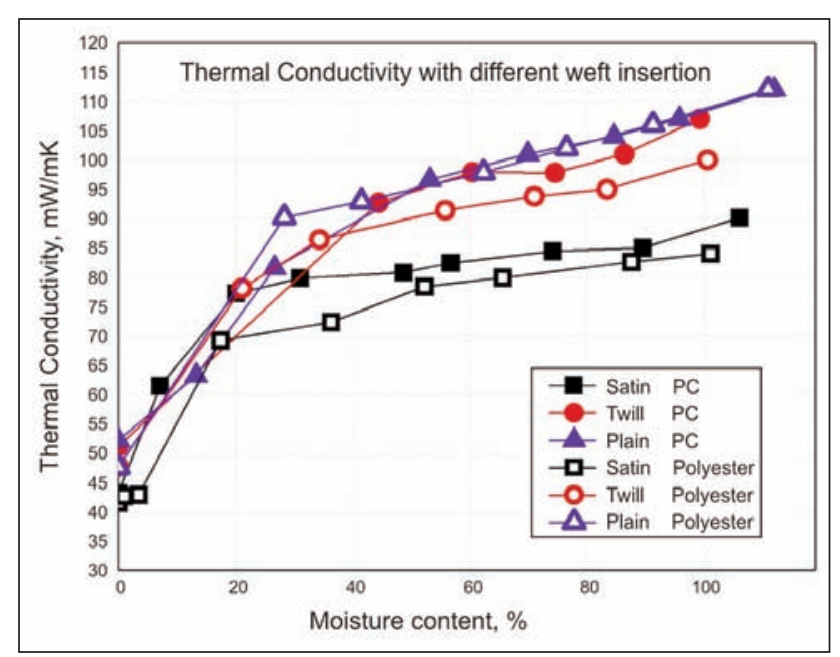

Fig. 2. Thermal conductivity of woven fabrics in wet state fabrics therefore thermal conductivity of wet fabrics enhanced with the increase in moisture content. In figure 2, graphical presentation showed that the thermal conductivity of samples increased favorably with the increase of fabric moisture content because water molecule substituted the entrapped air in the fabric structure.

Moreover, according to figure 2, there were two stages of moisture sorption:

1) Moisture content up to $20 \%$, thermal conductivity varies significantly with the fabric water content. As water droplet replaced the entrapped air in the pores, it became humidified rapidly. Weave structure appeared non-significant for this moisture content level as displayed in figure 2.

2) Higher moisture content $(\geq 20 \%$ ), thermal conductivity increased gradually with the moisture uptake. It was also observed a significant difference between the plain structure and other structures (twill and satin). In fact, the plain weaving structure revealed lower thermal conductivity. This phenomenon could be explained by the cover factor of this structure which was more compact leading to an entrapped air fraction in micro-pores more important than twill and satin weave design [19]. It was also noticed that twill and satin fabric design had the same cover factor apart from the plain weave.

Figure 2 also intimated the graphical trend of fiber composition in weft yarn. Thermal conductivity of fabrics made of $P C$ (50:50) yarn in weft was perceived higher than the fabric made of $100 \%$ polyester fabric. This phenomena occurred by the water absorption and swelling of the cotton fibers in fabric samples [20].

\section{Thermal absorptivity}

Thermal absorptivity $(b)$ is expressed in equation 1. An important aspect of evaluating the warm-cool feeling is the change of this feeling when textile products get wet. Since the thermal conductivity and thermal capacity of water in cotton is much higher than synthetic polymer fiber. The air entrapped in the textile structure, fabrics attains moisture by sweat; give a greatly changed warm-cool feeling when compared with the dry state.

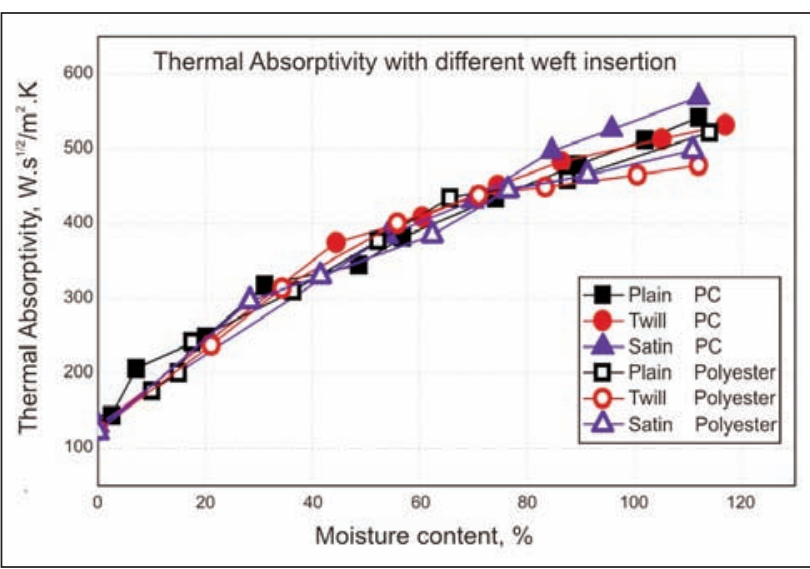

Fig. 3. Thermal absorptivity of woven fabrics in wet state 
When the human skin touches a garment with temperature difference, heat exchange occurs between the hand and the fabric, and the warm-cool feeling is the first sensation. Fabric with low value of thermal absorptivity gives a warmer feeling. The better feelings depend on the customer mind satisfaction; for summer garments a cool hand feel is demanded, whereas a warmer feeling is preferred for winter [15]. Thermal absorptivity increases with the increasing of thermal conductivity as given in equation 1.

According to figure 3, there was no effect of weaving structures up to $75 \%$ moisture content. However, over $75 \%$ it was observed that twill and satin fabrics disclosed minor thermal absorptivity resulted in warm feeling.

The fabrics made of polyester weft yarn expressed warmer feeling, whereas fabric with PC yarn in weft direction demonstrated comparatively cool feeling. This could be explained that fibers of higher equilibrium humidity provided a cooler feeling because thermal conductivity and thermal capacity of water was much higher than those of polymer fiber and the air entrapped in the textile structure [21].

\section{Water vapour permeability in wet state}

The heat loss by the body creates the cooling effect due to the heat flow generated by the sweat evaporation. However, cool felling also affects the heat flow evaporates from the surface of fabric due to moisture as drawn in figure 4 [22].

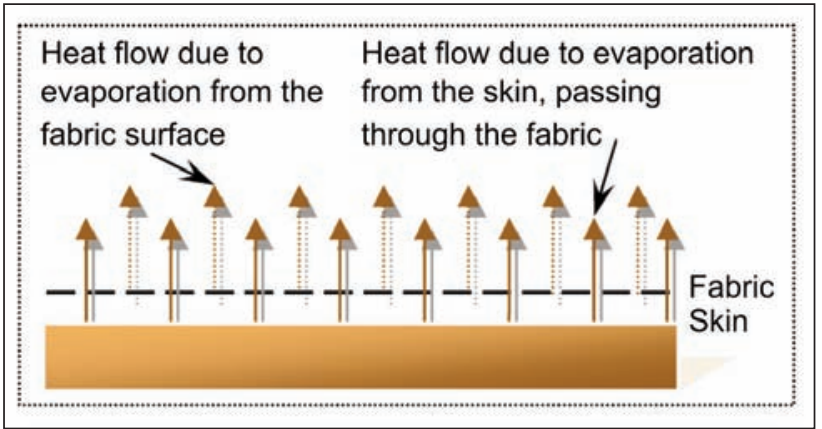

Fig. 4. Heat flow generation due to sweat evaporation from the skin surface and moisture evaporation from the fabric surface

The effective relative water vapour permeability (RWVP) of wet fabrics was also determined. The total relative cooling flow $\left(q_{\text {total }}\right)$ transferred through the boundary layer of the wet fabric surface is given by the sum of relative heat (cooling) flow passing from the skin through the permeable fabric $\left(q_{\text {fabric }}\right)$ and relative heat flow $\left(q_{\Delta t}\right)$ caused by temperature gradient between skin and fabric surface, which is cooled by evaporation of water from the fabric surface

$$
\begin{aligned}
& q_{\text {total }}=q_{\text {fabric }}+q_{\Delta t} \\
& q_{\text {fabric }}=q_{\text {total }}-q_{\Delta t}
\end{aligned}
$$

Equations 3 and 4 relates the heat flow passing through the free wet porous surface of the measuring head $\left(q_{0}\right)$ which simulates the sweating of human skin. Therefore, the term "relative" was introduced in this equation. Relative water vapour permeability (RWVP) of dry fabric is then defined as:

$$
R W V P=100 \cdot \frac{q_{\text {fabric }}}{q_{0}}
$$

Where, $q_{\text {fabic }}$ is the heat flow measured by the PERMETEST.

When the measuring head was covered by a dry fabric, RWVP of dry fabric was in fact the relative cooling flow passing through the dry fabric multiplied by 100. Similarly, the effective relative water vapour permeability $(E R W V P)$ is defined as "100 times the relative heat flow passing from the skin through the permeable fabric $\left(q_{\text {fabric }}\right)$ " (equation 4$)$.

In order to determine the ERWVP by means of the PERMETEST instrument, two different measurements were necessary on the same wet sample. In the first step, the relative cooling heat flow $\left(q_{\text {total }}\right)$ (equation 3) passing through the wet sample and also the cooling flow generated by the wet sample surface were measured. In the second step, the measuring head of the PERMETEST instrument was covered by an impermeable foil, which restricted the effective relative cooling flow $\left(q_{\text {fabric }}\right)$ through the wet fabric. Thus, in the second step, it was only measured the relative cooling flow $\left(q_{\text {fabric }}\right)$ of wet fabric surface. The difference between both the mentioned measurements yields the required relative cooling flow $\left(q_{\text {fabric }}\right)$, which after multiplying by 100 also presents the ERWVP as shown below (figure 5):

$$
E R W V P=100 \cdot q_{\text {fabric }}=100 \cdot\left(q_{\text {total }}-q_{\Delta t}\right)
$$

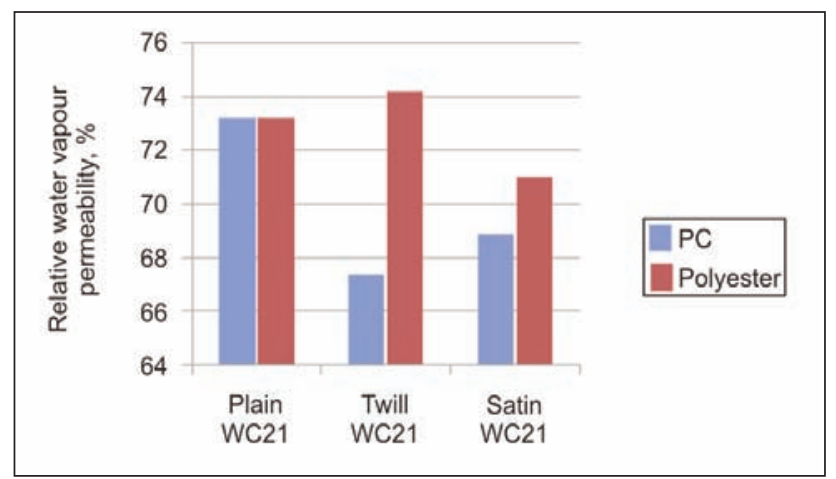

Fig. 5. RWVP of different woven fabric in dry state

Water vapor permeability gives the ability to transmit vapor from the body. Higher moisture resistance with high thermal resistance of the textile layers produces more heat storage on body skin causes uncomfortable sensation. RWVP of both PC and polyester weft inserted fabric samples (plain weave) manifested same behavior as displayed in figure 6. Difference in WVP of twill and satin weave as compared to plain was the consequence of variation in thickness of the fabric and composition of yarn used for weft lodging. 


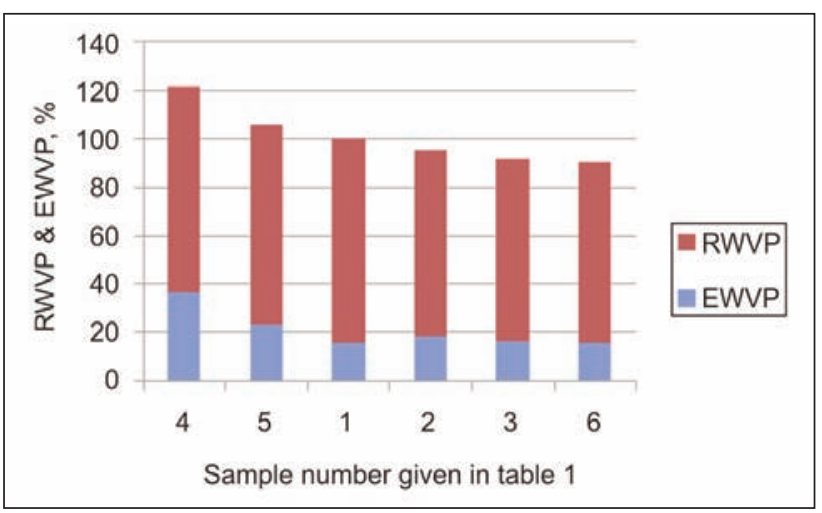

Fig. 6. Relative WVP or relative cooling heat flow of all tested fabrics at the $50 \%$ fabric moisture content consisting of real vapor transfer through the wet fabric (bottom level) and of evaporation from the fabric surface (upper level)

\section{CONCLUSIONS}

In this work, ALAMBETA and PERME tester (skin model) were utilized to simulate the complex thermal feelings in wet sate felt by wearers. Satin weave structure offered lower thermal conductivity because of its less yarn interlacing as compared to plain and twill and fabrics made from polyester weft inserted yarn offered cool feeling when get in contact with the skin.

Woven fabric samples were constructed by varying the weave design and weft composition. In wet state, moisture content up to $20 \%$, weave structures exhibited non-significant behavior for thermal properties due to air fraction. As the moisture content enhanced, woven structure made with polyester weft yarn provided cooler feeling with skin contact.The thermal properties for moisture content up to $20 \%$ exhibited non-significant effect with weave design variable. This occurred due to air fraction which was almost the same for all samples. Whereas the moisture content greater than $20 \%$ reported the non-significant trend concerning thermal absorptivity. Furthermore it was also observed non-significant effect of fibre composition used in filling for fabrication of samples.

In wet state if the fabric, total relative cooling heat flow comprised not only flow transferred through the fabrics, but also involved moisture evaporation flow from the fabric surface. The liquid water in wet fabric structure created a partial continuous film, which limited the transfer of water vapor. The obtained results of WVP measurement in wet state confirmed the direct relation of fabric moisture and WVP. Experimental study proved a correlation between WVP and physiological properties of the fabric in wet state followed by the adverse outcome of fabric quality with continuous wet condition. Knowledge of these phenomena can be exploited in clothing comfort technology in severe weather conditions with high humidity.

\section{BIBLIOGRAPHY}

[1] Watkins, D.A., Slater, K. The moisture vapor permeability of textile fabrics. In: Journal of Textile Institute, 1981, vol. 72, pp. 11-18

[2] Mallikarjunan, K., Ramachandran, T., Manohari, B.G. Comfort and thermo physiological characteristics of multilayered fabrics for medical textiles. In: Journal of Textile and Apparel, Technology and Management, 2011, vol. 7, pp. 1-15

[3] Li, Y. The science of clothing comfort. In: Textile Progress, 2011, vol. 31 p.1/2, pp. 1-135

[4] Chakraborty, S., Kothari, V.K. Effect of moisture and water on thermal protective performance of multilayered fabric assemblies for firefighters. In: Indian Journal of Fibre \& Textile Research, 2017, vol. 42, pp. 94-99

[5] Unal, P.G., Ureyen, M.E. Mechanical and permeability properties of sportech fabrics. In: Industria Textila, 2016, vol. 67, no. 3, pp. 151-156

[6] Baczek, M., Hes, L. Effective water vapour permeability of wet wool fabric and blended fabrics. In: Fibres \& Textiles in Eastern Europe, 2013, vol. 21, no. 1(97), pp. 67-71

[7] Hes, L., Sluka, P. Introduction into clothing comfort. Textbook of Technical University of Liberec, 2005

[8] Gibson, P.W. Factors influencing steady-state heat and water-vapour transfer measure for clothing materials. In: Textile Research Journal 1993, vol. 63, no. 12, pp. 749-764

[9] Ren, Y., Ruckman, J.E. Water vapour transfer in wet waterproof breathable fabrics. In: Journal of Industrial Textiles, 2003, vol. 32, no. 3, pp. 165-175

[10] Özdemir, H. Thermal comfort properties of clothing fabrics woven with polyester/cotton blend yarns. In: AUTEX Research Journal, 2017, vol. 17, no. 2, pp. 135-141

[11] Schneider, A.M., Hoschke, B.N., Goldsmid, H.J. Heat transfer through moist fabrics. In: Textile Research Journal, 1992, vol. 62, no. 2, pp. 61-66

[12] Hes, L., Loghin, C. Heat, moisture and air transfer properties of selected woven fabrics in wet state. In: Journal of Fiber Bioengineering and Informatics, 2009, vol. 2, no. 3, pp. 141-149

[13] Chen, Q., Zhao, T. The thermal decomposition and heat release properties of the nylon/cotton, polyester/cotton and Nomex/cotton blend fabrics. In: Textile Research Journal, 2015, vol. 86, no. 17, pp. 1859-1868 
[14] Ahmad, S., Ahmad, F., Afzal, A., Rasheed, A., Mohsin, M., Ahmad, N. Effect of weave structure on thermophysiological properties of cotton fabrics. In: AUTEX Research Journal, 2015, vol. 15, no. 1, pp. 30-34

[15] Hes, L. Thermal properties of nonwovens. In: Proceedings of Congress Index, 1987, vol. 87, Geneva.

[16] Hes, L., Araujo, I. Simulation of the effect of air gaps between the skin and a wet fabric on resulting cooling flow. In: Textile Research Journal, 2010, vol. 80, no. 14, pp. 1488-1490

[17] Hes, L., Dolezal, I. A new portable computer controlled skin model for fast determination of water vapour and thermal resistance of fabrics. In: Asian Textile Conference, 2003, ATC 7, New Delhi

[18] ISO 11092 Standard, Textiles - Physiological effects - Measurement of the thermal and water vapor resistance

[19] Benltoufa, S., Fayala, F., BenNasrallah, S. Capillary rise in macro and micro pores of jersey knitting structure. In: Journal of Engineered Fibers and Fabrics, 2008, vol. 3, no. 3, pp. 47-54

[20] Benltoufa, S., Fayala, F., BenNasrallah, S. Determination of yarn and fiber diameters after swelling using a capillary rise method. In: Journal of the Textile Institute, 2012, vol. 103 no. 5, pp. 517-522

[21] Özdil, N., Marmaralı, A., Kretzschmar, S.D. Effect of yarn properties on thermal comfort of knitted fabrics. In: International journal of Thermal sciences, 2007, vol. 46, no. 12, pp. 1318-1322

[22] Bączek, M., Hes, L. The effect of moisture on thermal resistance and water vapour permeability of Nomex fabrics. In: Journal of Materials Science and Engineering 2011, vol. 1, no. 3, pp. 358-366

Authors:
AMAL BOUGHATTAS ${ }^{1}$
SOFIEN BENLTOUFA ${ }^{1}$
LUBOS HES ${ }^{2}$
MUSADDAQ AZEEM ${ }^{2}$
FATEN FAYALA ${ }^{1}$
Monastir University, National School of Engineers, Department of Textile Engineering, Laboratoire d'Etudes des
Systèmes Thermiques et Energétiques (LESTE Laboratory), Avenue Ibn Eljazzar-5019 Monastir, Tunisia
${ }^{2}$ Technical University of Liberec, Faculty of Textile Engineering,
Studentska 1402/2, 461 17, Liberec 1, Czech Republic
Corresponding author:
AMAL BOUGHATTAS
e-mail: boughattasamal@gmail.com

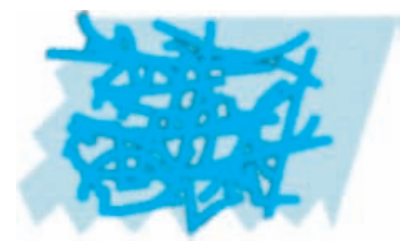

